\title{
Editing a Scientific Journal on Communication Disorders in South Africa: A Unique Challenge*
}

\author{
Brenda Louw \\ Department of Communication Pathology \\ University of Pretoria
}

\begin{abstract}
The aim of this article is to describe the challenge of editing a scientific journal in the field of communication disorders in the South African context. An overview of the development of the journal and the current editorial policy is described. The distinctiveness and uniqueness of the journal is highlighted. A discussion of the problems encountered and the challenges posed by the future is supplied. In conclusion the question is posed of whether a scientific publication of this nature is relevant and justifiable. It is concluded that such a publication is indeed important and has the right of existence.
\end{abstract}

\section{OPSOMMING}

Die doel van die artikel is om die uitdaging te beskryf wat die redaksie van 'n wetenskaplike tydskrif in die vakgebied van kommunikasiepatologie in die Suid-Afrikaanse konteks bied. 'n Oorsig van die geskiedkundige ontwikkeling van die tydskrif en die huidige beleid word bespreek. Die onderskeidende en andersoortige aard van die tydskrif word uitgelig en probleme in die redaksie en produksie van die tydskrif word geïdentifiseer. Uitdagings en moontlike oplossings vir die bestaande probleme word aangespreek. Ten slotte word die relevansie van 'n wetenskaplike publikasie van hierdie aard beuraagteken. Die gevolgtrekking word bereik dat so 'n publikasie wel bestaansreg het.

Writing and publication are important in developing the scholarly base of speech-language therapy and audiology. Scholarly journals serve as archives of research data, contain literature reviews, and other types of materials that contribute to the scientific base of a discipline or that have broad and lasting clinical relevance. Because knowledge is ever-changing and advancing, the facts and findings published at any one point in time may become dated or proven incorrect. Nevertheless, the hallmark of a scholarly publication is that it represents the current state of art or science at the time of publication (ASHA, 1993).

The practice of the profession of speech-language therapy and audiology in South Africa has been reflected and supported by it's own scholarly journal over the years. The editing of this scientific journal poses unique challenges to the editor. The aim of this article is to describe these challenges by supplying an overview of The South African Journal of Communication Disorders, describing the distinctiveness and uniqueness of the journal, identifying the problems encountered and providing possible solutions in meeting these problems.

The aim of The South African Journal of Communication Disorders is to publish papers or reports con- cerned with research, and critically evaluative theoretical and philosophical conceptual issues dealing with aspects of human communication and its disorders, service provision, training and policy. It serves as the scientific mouthpiece for local members of the profession and mirrors the professional and theoretical trends within the local context by publishing both research and review articles.

A historical overview indicates that the profession of speech-language-therapy and audiology has been practiced in South Africa since the late 1930's. Prof. Pierre De Villiers Pienaar initiated the training of speech-language-therapists and audiologists at the University of the Witwatersrand in 1937, and the course is currently taught at five universities in South Africa (Uys, 1993). The South African Journal of Communication Disorders was first published by the South African Speech, Language, Hearing Association (SASLHA) in 1953 and the fortieth volume appeared in 1993. The journal is published annually. Throughout the forty years of publication the journal has undergone three title changes, from "Journal of the Logopaedic Society" to "Journal of the South African Speech and Hearing Association" to the current title, reflecting changes within

\footnotetext{
* This article is based on a paper of the same title presented at the International Conference on Biomedical Periodicals,
} Beijing, China, June 16-18, 1994. 
the field and the association. The current title reflects the underlying paradigmatic shift of the profession in the South African context.

The editorial policy is published in every issue and employs the peer review system (Strayhorn, McDermott \& Tanquay, 1993). Peer review has become an important aspect of quality control in scientific publications. Peer reviewers are experts in the topic of a submitted manuscript who are considered "peers" of the authors, and who are selected by the editor to assess the quality of the manuscript's scientific and technical content. The editor remains responsible for decisions regarding rejection, revision, or acceptance of publication (Glass, 1994). This process of refereeing, or editorial peer review, increases the credibility of a journal by assuring that only scientifically sound research is published (Weller, 1987).

Although The South African Journal of Communication Disorders is comparable to other journals in the field published in the United Kingdom, Australia and the United States of America, it is distinctly different from these publications and has a unique character.

The distinctiveness and uniqueness of the journal is embedded in the fact that two distinct, yet integrated, fields of speech-language pathology and audiology in which training is done, are represented by the journal, leading to diverse topics and research methodologies reflecting the differing nature of the two fields. In addition articles are published in the two (up till 1993) current official languages of South Africa, English and Afrikaans, thus rendering the journal to be bilingual. South Africa represents a multilingual, multicultural society and articles increasingly reflect the diversity of the communication disorders and underlying issues encountered in this context.

Circulation figures of the journal are limited (approximately 800 ) which is ascribed to the fact that there were 980 speech-language therapists/audiologists registered with the South African Medical and Dental Council in 1993, of whom approximately 650 are members of SASLHA and subscribe to the journal as part of their membership. This differs greatly from, for example, the membership figures of the American SpeechLanguage Hearing Association (ASLHA), with an approximate membership of 70000 (ASHA, 1994). Members of ASLHA selectively subscribe to the various journals published by their association.

Lastly, the uniqueness of the journal is related to geographical and political factors, as South Africa has been relatively isolated from international contact (Aron, 1991). This has led to limited international contributions and has characterized the journal with a unique South African perspective.

It is therefore clear that the journal is distinct from others published in the field internationally, and in order to retain this uniqueness and to be truly representative of the context in which it appears, the editor is faced with exciting challenges.

The challenges facing the editor of The South African Journal of Communication Disorders are twofold, those relating to the general problems of scholarly journals and those stemming from the distinctiveness of the journal.

According to Leslie (1989) scholarly journals have numerous problems. Although many scientific journals are published, only very few can be labelled as quality journals due to various reasons, e.g., some lack central focus, others are too focussed and reject submissions if the content does not fit prescribed research agenda. A central problem to scholarly journals is manuscript review (Leslie, 1989). The need for peer review is generally conceded, but the operation of the system is fraught with controversies e.g., conflicts of interest, importance of articles, masking of identities during peer review, and reviewer bias (Grassman, 1986; Siegelman \& Whicker, 1987; Glass, 1994).

Leslie (1989) expressed the opinion that the time to examine these problems, and to search for an implement solutions is at hand. He poses the following question: Do we have the courage to begin this impor. tant work? (Leslie, 1989, p. 128). The answer is yes, as these problems are being addressed internationally by conferences, task groups and public actions in order to improve the quality of journals and to develop the editing process of scholarly journals into a profession (Glass, 1994).

When confronted by Leslie's (1989) question and international developments, it is clear that the problems of The South African Journal of Communication Disor. ders need to be identified and solutions proposed to ensure the continuation of the forty year old tradition of the journal.

In response to these challenges and developments, the author who is the current editor of the journal, conducted a critical appraisal of the publication process of the The South African Journal of Communication Dis. orders and of literature relating to editorial and publication issues. The following eight problems were identified and addressed. Many of the problems relate to the distinctive nature of the journal, as discussed earlier.

Firstly the language in which articles are written poses a problem. For example, articles written in Afrikaans are not accessible to all subscribers. To write a scientific manuscript in a second language is problematic and professional translation is costly and does not usually convey the exact meaning of the author. Imminent political changes, however, may designate English as one of the official languages which could necessitate changes in editorial policy.

The number of speech-language therapists and audiologists from different linguistic and cultural backgrounds is increasing and will hopefully lead to an increased research on communication disorders in the various cultural and linguistic groups as well as in intercultural research, which is urgently needed in the field. Designating the publication of all articles in one language, namely English, will make information reasonably accessible to most professionals in the field, as opposed to publishing articles in the author's first language. Abstracts may then be published in the author's first language or in a chosen second language. This implies that the editor would need to make use of additional resources in editing the second language abstracts, but would emphasize the distinctive nature of the journal.

Secondly, although South Africa represents a multilingual, multicultural society and poses unique challenges to service delivery, The South African Journal of Communication Disorders has not adequately developed 
a distinct local character. The journal has been modelled on journals published by the American Speech-Language Hearing Association. A possible solution could be to increase the journal's scholarly impact by specifically developing the multilingual, multicultural aspects (as mentioned above) and developing the perspective of the profession contextualized in an intersectoral, transdisciplinary context of an integrated health care system. Such an approach would provide a truly distinctive character to the journal. It could also contribute to the procuring of funding if the journal took on a new, strongly developed unique character, with a definite transformatory human rights perspective. This is consistent with the theoretical paradigm underlying the discipline, namely that the communication of an individual is always viewed in the context of social systems.

Thirdly, few professionals are willing to serve on the editorial board. Professionals appear to be willing to act as reviewers, but not to become involved on any other level of management of the journal. This may be attributed to the "burn-out" phenomena within the profession (Swidler \& Ross, 1993). According to Weller (1987) journal quality is affected by the editorial staff. The implications of a limited editorial board are an increase in the editor's responsibilities regarding the peer review process, placement decisions, and the lack of a support mechanism on both a technical and emotional level. A proposed solution to this pressing problem is that the editor actively recruits members for an extended editorial board by clearly stating the advantages of being involved in the publication process of a scholarly journal. Master degree level students could be motivated to serve as editorial staff members by expounding the benefits of being actively involved in the development of the data basis of the field of speech-language pathology and audiology. Lastly, the editor can approach employers to recognize the importance of and benefits of employees participating in the editorial process of the journal, by crediting the individuals for promotion purposes, research grant or subsidy applications.

Fourthly, as mentioned previously, the circulation figures of the journal are limited, implying small financial gain and reader audience Increasing circulation figures may serve as a solution to both financial problems and the reader audience. This can be affected by recruiting student members and an active public relations drive of the SASLHA and the journal itself. Increased international contact may encourage new contributors, but the relevance of such contributions and the unique local character of the journal must not be compromised.

Fifthly, given the limited circulation figures, it follows that the source of contributors to the journal is also very limited. Five universities offer undergraduate training in the field, thus contributors from the academia are a small group. Relatively few professionals in clinical practice contribute to the journal, mainly due to two reasons. The workload created by the imbalance that exists between professional and communicatively disordered in the South African context (Uys, 1993), allows for little time allocated to conducting scientific research and the writing of articles. Secondly, only a small corps of professionals in the field actively conduct research, and even fewer are prepared to devote time to writing articles on conceptual issues related to the fields of speech-language pathology and audiology. A viable solution is to publish articles based on outstanding student research reports. This not only reflects the current development and interest at the various training centres, but also makes interesting research findings available and contributes to the data base of local research. In giving this guidance to student researchers the journals are contributing to a genre of graduates with the skills and attitudes relevant to a "culture" of publishing. According to Silverman (1988) clinical research needs to be encouraged as it is beneficial to both the communicatively handicapped population and to members of the profession. The communicatively handicapped population can benefit by the publication of clinical research results as the sharing of information by professionals leads to higher quality services. Professionals benefit from conducting clinical research as it allows them to satisfy a requirement of the profession's code of ethics; reduces "burn-out"; and improves clinical effectiveness (Silverman, 1988). The questions, answers and implications of empirical and clinical research must, however, be communicated to potential consumers before they can have impact on the quality of services for the communicatively handicapped. According to Silverman (1988) reporting information in professional journals is the most effective manner to reach large audiences. Different kinds of incentives can be created by institutions to encourage clinical investigations and clinical researchers can be accommodated to enable them to conduct research. The editorial board of the journal can take the initiative and approach institutions in this regard to ensure a constant flow of articles to be submitted for publication. According to Yoder Wise (1992) writing is a professional commitment that requires planning and dedication. Scholarly journals need to strive to help authors in their development of manuscripts in order to create an important body of knowledge in a discipline (Yoder Wise, 1992).

Sixthly, the peer review process employed by the journal poses many problems. According to Yoder Wise (1992) publication in a peer-reviewed journal should be a mark of distinction. This system is, however, fraught with problems (Siegelman \& Wicker, 1987; Oxman, 1991; Abdellah, 1990). Two striking aspects of peer review are that it is based almost entirely on uncompensated voluntary work, and that the peer review system itself has only recently come under scientific scrutiny. Although peer review is viewed as a major facet of the evaluation of science, it is subject to human error. This pillar of science merits scientific research to refine the process and to develop a stricter application of scientific standard (Glass, 1994). The editorial board thus needs to keep abreast with recent international trends of article reviewing and select peer reviewers with care to ensure that the peer review system is practiced optimally (Leslie, 1989; Strayhorn, McDermott \& Tanquay, 1993; Lightdale, 1992; Grassmann, 1986).

In addition to the problems of peer review as identified in the literature, the context in which this journal is published, leads to additional problems such as the limited corps of reviewers available and the fact that not all reviewers are able to effectively review a scientific article in a second language. Certain criteria are, however, used as an aid to the peer review process in an attempt to increase the cred- 
ibility of the journal by assuring that only scientifically sound research and review articles of scientific quality are published (Oxman, 1991; Weller, 1987).

Seventhly, funding for the journal is problematic due to the current financial climate in South Africa and the limited sources of SASLHA. The journal receives a grant from The Foundation for Education, Science and Technology with SASLHA having to bear the brunt of the costs. Funding determines the continuation of a publication to a large extent and alternatives will need to be found if the tradition of the journal is to be continued. Recruiting an increased number of advertisements could increase the journal's income to assist in publication costs. The financial challenge is partially met by desk top publishing, which necessitates disk copies of the submitted articles and ensuring that the articles which are accepted for publication, are print ready. Printing from "print ready" software reduces the printing costs dramatically and shortens the printing process.

Desk top printing, however, creates another editorial problem. In the South African context, papers tend to be submitted in grossly unedited forms. Due to the limited source, mentioned earlier, competition is mini$\mathrm{mal}$ and papers are accepted and then have to go through a long editorial process before being "print ready". A possible solution to this problem may be the expansion of the information for contributors which is contained in each issue of the journal and strict adherence to these guidelines by the authors. The editor should also retain the right to refuse publication of an accepted article if the set requirements of editorial care are not met.

Eighthly, the post of editor of The South African Journal of Communication Disorders is a voluntary one and financially uncompensated, which implies that the editor practices this portfolio in a part-time capacity, while usually employed in another full-time post. The demands of editing are great and according to Weller (1987) the quality of a journal is affected by the continuity of good editors. In order to meet these challenges scholarly journals must provide editors with sufficient resources to do their jobs. According to Leslie (1989, p. 126) the solution is to have the journal sponsor, whether a professional, academic, research organization or university (or a combination of these) provide editors with time, money, personnel, and equipment. If the publication of scholary work is important, it deserves this kind of commitment (Leslie, 1989). The editor must actively campaign for these benefits in order to function appropriately. Effective editorial management can make an important contribution to the continuity and quality of the journal.

Maintaining quality and standards of the journal in the given circumstances requires a concentrated effort to continue the international recognition the journal currently enjoys and to diligently carry out administration adequately so as to maintain international listing and abstracting of the journal. According to Weller (1987) the quality of a journal is determined by the following factors - the editorial staff, contributors, and refereeing process, the visual aspects of the journal and the continuity of good editors and authors (Weller, 1987). By being aware of and addressing these contributing factors, the journal editor can function in an accountable fashion and ensure a quality product.

Despite the wide range of problems identified in pub- lishing The South African Journal of Communication Disorders, it appears that many solutions can be imple. mented to minimize, and even overcome these deterrents to a successful publication.

\section{CONCLUSION:}

The ultimate challenge posed to the editor of The South African Journal of Communication Disorders is whether a scientific publication in the fields of SpeechLanguage Pathology and Audiology is at all relevant in the South African situation? The alternative to a scientific publication is a more informal dissemination of clinical information. According to Silverman (1989) this can be done by means of newsletters, study groups and informal communication between clinicians. Another possible solution could be to abandon the discipline of specific journals that tend to lead to fragmentation in the South African context. Instead, other disciplines such as e.g., occupational therapy, physiotherapy, psychology, general medical practice, could be involved to promote the concept of a transdisciplinary approach in meeting the needs of the people in an integrated health care system.

Based on the following argument it is concluded that the publication of The South African Journal of Communication Disorders is indeed important and needs to be continued in the future. Publishing articles in a peerreviewed journal is a mark of distinction. The time and effort invested in the publication process by the author, the reviewers and the editor is justified to help create an important body of knowledge in the field (Yoder Wise, 1992). This is specifically true of the South African situation in which a dirth of knowledge still exists regarding communication disorders and service delivery in the local context. Research on the needs of the culturally and linguistically diverse population of South Africa is needed in order to make clinical applications and to increase the effectiveness and accountability of service delivery. By publishing articles on issues dealing with communication disorders, service provision, training and policy the scientific journal supports the profession of speech-language pathology and audiology in taking responsibility for shaping its own future (Cole, 1986; Uys, 1993).

\section{ACKNOWLEDGEMENTS}

The author wishes to thank Glen Jager, previous editor of The South African Journal of Communication Disorders, and Prof. René Hugo for their valuable contribution in peer-reviewing this article.

The financial assistance received from the Centre for Science Development, HSRC and the University of Pretoria is acknowledged with appreciation.

\section{REFERENCES}

Abdellah, F.G. 1990. Peer review - the only answer to highquality research? Journal of Professional, Nursing, $6, \mathrm{pp}$ 70-75.

Aron, M.L. (1991). Perspectives. The Soúth African Journal of Communication Disorders, 38, pp. 3-12.

ASHA. (1993). The Publication Process. A Guide for Authors. ASHA, 37, pp 142-144.

ASHA. (1994). Changing Courses Midstream. ASHA, 38, pp
38-39. 
Cole, P.R. (1986). I want to shape my own future. How about you? ASHA, 28, pp. 41-42.

Glass, R.M. (1994). Peer Review and Quality Control in Biomedical Publication. International Conference on Biomedical Periodicals, Abstracts, p. 1.

Grassmann, W.K. (1986). Is the fact that the Emperor wears no clothes a subject worthy of publication? Interfaces, 16, pp 42-51.

Leslie, L.Z. (1989). Manuscript review: A view from below. Scholarly Publishing, 20 pp. 123-128.

Lightdale, C.J. (1992). The editor : professor or journalist? Gastrointestinal Endoscopy, 38, pp 193-194.

Oxman, A.D. (1991). Agreement among reviewers of review articles. Journal of Clinical Epidemiology 44, pp. 91-98.

Siegelman, L. \& Whicker, M.L. (1987). Some implications of bias in peer review: a simulation based analysis. Social Science Quarterly, 68, pp. 494-509.

Silverman, F.H. (1988). Speech Language Pathology and
Audiology. Columbus: C E Merrill Publ. Co.

Strayhorn, J., Mc Dermott \& J.F. Tanquay, P. (1993). An intervention to improve the reliability of manuscript reviews for the Journal of the American Academy of Child and Adolescent Psychiatry. American Journal of Psychiatry, 150 (6), pp. 947-952.

Swidler, M. \& Ross, E. (1993). Burn-out: A smouldering problem among South-African speech-language pathologists? The South African Journal of Communication Disorders, 40, pp. 71-84.

Uys, I.C. (1993). Kommunikasiepatologie: Onderrig vir die toekoms. Die Suid-Afrikaanse Tydskrif vir Kommunikasieafwykings, 40, pp. 3-10.

Weller, A.C. (1987). Editorial policy and the assessment of quality among medical journals. Bulletin of Medical Library Association, 75, pp. 310-316.

Yoder Wise, P. (1992). From manuscript to publication. Journal of Continuing Education in Nursing, 23, p. 51. 


\section{INFORMATION FOR CONTRIBUTORS}

The South African Journal of Communication Disorders publishes reports and papers concerned with research, and critically evaluative theoretical and philosophical conceptual issues dealing with aspects of human communication and its disorders, service provision, training and policy.

The South African Journal of Communication Disorders will not accept material which has been published elsewhere or that is currently under review by other publications

\section{MANUSCRIPT STYLE AND REQUIREMENTS}

Manuscripts should be accompanied by a covering letter providing the author's address and telephone numbers. All contributions are required to follow strictly, the style specified in the Publication Manual of the American Psychological Assoc. (3rd ed., 1983)(APA Pub. Man.), with complete internal consistency. Four copies of triple-spaced high quality type-written manuscripts with numbered pages, and wide margins should be submitted. They should be accompanied by ONE identical disc copy of the paper; (1) in Wordperfect 5.1 (with an extension .wp5). Filenames should include the first author's initials and a clearly identifiable keyword or abbreviation thereof and should be typewritten on the last line of the last page of the Reference List (for retrieval purposes only).

As a rule, contributions should not exceed much more than 30 pages, although longer papers will be accepted if the additional length is warranted. The first page of TWO copies should contain the title of the article, name of author(s), and institutional affiliation (or address). In accordance with the APA Pub. Man. style $(1833$, p.23) authors are NOT required to provide qualifications. In the remaining two copies, the first page should contain only the title. The second page of all copies, should contain only an abstract (100 words), written in English and Afrikaans. Afrikaans abstracts will be provided for overseas contributors. Major headings where applicable should be in the order of METHOD, RESULTS, DISCUSSION, CONCLUSION, ACKNOWLEDGEMENTS, REFERENCES. All paragraphs should be indented.

TABLES AND FIGURES which should be prepared on separate sheets (one per page), should be copied for review purposes and only the copies sent initially. Figures, graphs, and line drawings that are used for publication, however, must be originals, in black ink on good quality white paper, but these will not be required until after the author has been notified of the acceptance of the article. Lettering appearing on these should be uniform and professionally done, allowing for a $50 \%$ reduction in printing. On no account should lettering be typewritten on the illustration. Any explanation or legend should appear below it and should not be included in the illustration. 'The titles of tables, which appear above, and figures, which appear below, should be concise but explanatory. Both should be numbered in Arabic numerals in order of appearance. The number of illustrative materials allowed, will be at the discretion of the Editor (usually about 6 ).

\section{REFERENCES}

References should be cited in the text by surname of the author and the date, e.g., Van Riper (1971). Where there are more than two authors, after the first occurrence, et al. after the first author will suffice, except for six or more when et al. may be used from the start. The names of all authors should appear in the Reference List, which should be listed in strict alphabetical order in triple spacing at the end of the article. All references should be included in the List, including secondary sources, (APA Pub. Man. 1983, p.13). Only acceptable abbreviations of journals may be used, (see DSH ABSTR $\Lambda$ CTS, October; or The World List of Scientific Periodicals). The number of references should not exceed much more than 30 , unless specifically warranted.

\section{EXAMPLES}

Locke, J.L. (1983). Clinical psychology: The explanation and treatment of speech sound disorders. J. Speech Hear. Disord., 48 339-341.

Penrod, J.P. (1985). Speech discrimination testing. In J. Katz (Ed.), Handbook of clinical audiology (3rd ed.). Baltimore: Williams \& Wilkins.

Davis, G.A. \& Wilcox, M.J. (1985). Adult aphasia rehabilitation: Applied pragmatics. San Diego, CA: College-Hill.

\section{EDITING}

Acceptable manuscripts may be returned to the author for revision. Additional minor changes may also be made at this stage, but a note on the manuscript acknowledging each alteration made by the author, is required. The paper is then returned to the editorial committee for final editing for style, clarity and consistency.

REPRINTS: 10 reprints without covers will be provided free of charge.

DEADLINE FOR CONTRIBUTIONS: the preferred date is the 31 st May each year, but papers will be accepted until 30 th $J_{u n e}$ by arrangement.

QUERIES, CORRESPONDENCE \& MANUSCRIPTS: should be addressed to The Editor, South African Journal of Communication Disorders, South African Speech-Language-Hearing Association, P.O. Box 600, Wits, 2050, South Africa. 


\section{INLIGTING VIR BYDRAERS}

Die Suid-Afrikaanse Tydskrif vir Kommunikasieafwykings publiseer verslae en artikels wat gemoeid is met navorsing, of handel oor krities evaluerende, teoretiese en filosofiese konseptuele kwessies wat oor menslike kommunikasie en kommunikasieafwykings, diensverskaffing, opleiding en beleid gaan.

Die Suid-Afrikaanse Tydskrif vir Kommunikasieafwykings sal nie artikels aanvaar wat reeds elders gepubliseer is, of wat tans deur ander publikasies oorweeg word nie.

\section{MANUSKRIP STYL EN VEREISTES:}

Manuskripte behoort deur'n dekkingsbrief vergesel te word wat die skrywer se adres en telefoonnommers bevat. Daar word van alle bydraers verwag om die styl, soos gespesifiseer is in die "Publication Manual of the American Psychological Assoc. (3rd ed., 1983) (APA Pub. Man."), nougeset te volg met volledige interne ooreenstemming. Manuskripte moet getik, van hoë gehalte en in drievoud spasiëring met wye kantlyne wees. Vier kopieë van die manuskrip moet verskaf word. EEN hiervan moet 'n identiese skyfkopie van die artikel wees in Wordperfect 5.1 (met 'n uitbreiding .wp5). Lêername behoort die eerste skrywer se voorletters en ' $n$ duidelike identifiseerbare sleutelwoord of afkorting daarvan in te sluit en moet op die laaste lyn van die bladsy van die verwsyingslys getik word (slegs vir naslaan doeleindeg).

As 'n reël moet bydraes nie 30 bladsye oorskry nie, maar langer artikels sal aanvaar word indien die addisionele lengte dit regverdig. Op die eerste bladsy van TWEE van die afskrifte moet die titel van die artikel, naam van die skrywer(s), en instansie (of adres) verskyn. In ooreenstemming met die "APA Pub. Man." se styl word daar NIE van skrywers verwag om enige kwalifikasies te verskaf nie. Op die eerste bladsy van die twee oorblywende afskrifte moet slegs die titel van die artikel verskaf word. Die tweede bladsy van alle afskrifte moet slegs 'n opsomming ( 100 woorde) in beide Engels en Afrikaans bevat. Afrikaanse opsommings sal vir buitelandse bydraers voorsien word. Hoofopskrifte moet, waar van toepassing, in die volgende volgorde verskaf word: METODE, RESULTATE, BESPREKINGS, GEVOLGTREKKINGS, ERKENNINGS en VERWYSINGS. Alle paragrawe moet ingekeep word.

TABELLE EN FIGURE wat op afsonderlike bladsye (een bladsy per tabel/illustrasie) moet verskyn, moet vir referent-doeleindes gekopieer word en slegs die kopieë moet inisieel verskaf word. Figure, grafieke en lyntekeninge wat vir publikasie gebruik word, moet egter oorspronklike weergawes wees en moet in swart ink op wit papier van 'n hoë gehaite wees. Die oorspronklikes sal slegs verlang word nadat die artikel vir publikasies aanvaar is. Letterwerk wat op bogenoemde verskyn, moet eenvormig wees, professioneel gedoen word en daar moet in gedagte gehou word dat dit leesbaar moet wees na 'n 50\% verkleining in drukwerk. Letterwerk by illustrasies moet onder geen omstandighede getik word nie. Verklarings of legendes moet nie in die illustrasie nie, maar daaronder, verskyn. Die opskrifte van tabelle (wat bo-aan verskyn), en die onderskrifte van figure, (wat onderaan verskyn), moet beknop, maar verklarend wees. Numering moet deur middel van Arabiese syfers geskied. Tabelle en figure moet in die volgorde waarin hulle verskyn, genommer word. Die aantal tabelle en illustrasies wat ingesluit word, word deur die Redakteur bepaal (gewoonlik nie meer as 6 nie).

\section{VERWYSINGS}

Verwysings in die teks moet voorsien word van die skrywer se van en die datum, b.v., Van Riper (1971). Wanneer daar egter meer as twee skrywers is, moet daar na die eerste verskaffing van al die outeurs, van $e t$ al. gebruik gemaak word. In die geval waar daar egter ses of meer outeurs ter sprake is moet $e t$ al. van die begin af gebruik word. Al die name van die skrywers moet in die Verwysingslys verskyn wat aan die einde van die artikel voorkom. Verwysings moet alfabeties in trippel spasiëring gerangskik word. Al die verwysings moet in die Verwysingslys verskyn, insluitende sekondêre bronne, ("APA Pub. Man." 1983, p.13). Slegs aanvaarbare afkortings van tydskrifte se titels mag gebruik word, (sien "DSH ABSTRACTS, October"; of The World List of Scientific Periodicals"). Die aantal verwysings moet nie meer as $\mathbf{3 0}$ oorskry nie, tensy dit geregverdig is.

\section{LET OP DIE VOLGENDE VOORBEELDE:}

Locke, J.L. (1983). Clinical psychology: The explanation and treatment of speech sound disorders. J. Speech Hear. Disord., 48, 339-341.

Penrod, J.P. (1985). Speech discrimination testing. In J. Katz (Ed.), Handbook of clinical audiology (3rd ed.). Baltimore: Williams \& Wilkins.

Davis, G.A. \& Wilcox, M.J. (1985). Adult aphasia rehabilitation: Applied pragmatics. San Diego, CA.: College-Hill.

\section{REDIGERING}

Manuskripte wat aanvaar is, mag na die skrywer teruggestuur word vir hersiening. Addisionele kleiner veranderinge mag ook op hierdie stadium aangebring word, maar'n nota ter aanduiding van alle veranderinge wat op die manuskrip voorkom, moet verskaf word. Die artikel word dan aan die redaksionele komitee vir finale redigering van styl, duidelikheid en konsekwentheid teruggestuur.

HERDRUKKE: 10 herdrukke sonder omslae sal gratis aan die outeurs verskaf word.

SLUITINGSDATUM VIR BYDRAES: Bydraes word verkieslik teen 31 Mei elke jaar verwag, maar artikels sal nog tot 30 Junie vir aanvaarding oorweeg word.

NAVRAE, KORRESPONDENSIE EN MANUSKRIPTE: moet geadresseer word aan Die Redakteur, Die Suid-Afrikaanse Tydskrif vir Kommunikasieafwykings, Die Suid-Afrikaanse Spraak-Taal-Gehoor Vereniging, Posbus 600, Wits 2050, SuidAfrika. 